Nunt. Antiquus, Belo Horizonte, v. 15, n. 2, p. 103-122, 2019

\title{
Cavalos que choram: cantos XVI e XVII da Ilíada e(m) registros de João Guimarães Rosa
}

\section{Crying Horses: Songs XVI and XVII from the Iliad and Some Notes Made by João Guimarães Rosa}

\author{
Lorena Lopes da Costa \\ Universidade Federal do Oeste do Pará (UFOPA), Santarém, Pará / Brasil \\ lorenalopes85@gmail.com
}

Resumo: Para estabelecer a relação entre Grécia e sertão, neste artigo, dedico atenção especial às vocalizações dos cavalos, tanto na Ilíada quanto na literatura ficcional de João Guimarães Rosa, mas também nas notas que o autor fez da leitura da poesia épica grega e no diário que ele escreveu na Alemanha durante a Segunda Guerra Mundial. Pretendo, com isso, demonstrar, por um lado, a recepção de um material antigo pela ficção de Rosa, que é incorporado à sua própria tradição literária, forjando uma nova. Por outro lado, como não posso afirmar (mas vou sugerir) que o autor brasileiro teria lido os verbos no idioma grego, veremos a capacidade que um "clássico" apresenta de participar de nossa história para além de caminhos verificáveis.

Palavras-chave: cavalos; guerra; Ilíada; João Guimarães Rosa.

Abstract: In order to establish the relationship between Greece and sertão, in this paper I devote special attention to the vocalizations by the horses both in the Iliad and in the fictional literature by João Guimarães Rosa, but also in the notes the author made from his reading of the Greek epic poetry and in the diary he wrote in Germany during the Second World War. I aim to demonstrate, on the one hand, the reception of an ancient material by Rosa's fiction, which is incorporated into its own literary tradition, forging a new one. On the other hand, because I cannot affirm (but I will suggest) that the Brazilian author would have read the verbs in Greek language, we will see the potential a "classic" presents to participate in our history beyond verifiable paths.

Keywords: horses; war; Iliad; João Guimarães Rosa. 


\section{Introdução}

Neste texto, exploro algumas cenas de cavalos na poesia épica grega e em duas obras ficcionais em prosa de João Guimarães Rosa. Para estabelecer a relação entre Homero e o autor brasileiro, vou me valer, contudo, não somente da análise de algumas passagens desse corpus literário, dedicando especial atenção às vocalizações dos equinos, mas também de registros de Rosa de outra natureza (como suas anotações de leitura da Ilíada e o diário que escreveu na Alemanha durante a Segunda Guerra Mundial). Com isso, quero demonstrar, por um lado, a recepção de um material antigo pela (e na) literatura rosiana, de forma a incorporálo em sua própria tradição, uma tradição sertaneja histórico-ficcional, mas também, porque não posso afirmar com todas as letras que o autor do sertão mineiro teria lido os verbos em grego homérico, quero ainda sugerir a capacidade dos clássicos de participarem de nossa história para além dos caminhos comprováveis. ${ }^{1}$

\section{Os cavalos no sertão rosiano}

No conto "A hora e a vez de Augusto Matraga" que compõe Sagarana (1946), há uma menção à égua. Rápida, mas significativa, a referência ao animal espelha a transformação da personagem principal, que dá nome à estória. Dado como morto duas vezes, Augusto Matraga precisará renascer quando da primeira morte para que chegue sua hora e sua vez. Esse renascimento acontece de forma processual, sendo a alusão à égua, porém, fulcral em seu desenrolar.

Como discuti em outra oportunidade, ${ }^{2}$ este conto de Sagarana reelabora alguns elementos próprios à épica grega homérica. Especialmente, são reelaboradas ali as ideias, já bem trabalhadas entre

\footnotetext{
${ }^{1}$ Este artigo foi iniciado e parcialmente desenvolvido durante uma temporada na Fundação Hardt, financiada pela mesma. À Fundação e ao Professor David Bouvier (Université de Lausanne), meu respeito e minha gratidão.

${ }^{2}$ Ver o artigo: Lorena Lopes da Costa, "Du héros épique au guerrier du 'sertão': les anciens chez João Guimarães Rosa", RITA [en ligne], n. 12, sept. 2019, mis en ligne le 12 sept. 2019. Disponible en ligne.
} 
os homeristas, de renome e bela morte. Prova disso é a maneira como Augusto Matraga se esforça para ter sua fama espalhada pelo sertão quando está prestes a morrer efetivamente, bem como a maneira como ele se esforça para não ter sua fama espalhada pelo sertão ao quase morrer, experimentando aquela que seria ainda sua primeira morte.

É depois dessa primeira (quase) morte, de anos de trabalho, da mudança com o casal que ele adota como pai e mãe para outra localidade, e de muito esforço em busca de redenção, que o personagem é descoberto por Tião da Tereza, proveniente de seu vilarejo de origem, e só conhecedor do velho e irascível Nhô Augusto Esteves, alguém que tinha notícia, portanto, de seu primeiro (quase) passamento, mas não de sua salvação. $\mathrm{O}$ visitante não economiza nas notícias que dá a Matraga: sua esposa, agora casada e feliz com outro, acabara de ter um filho; sua filha se prostituíra, deixando pouco rastro de seu paradeiro; e seu mais fiel serviçal havia morrido quando tentara vingar sua honra. As novidades, claro, afetam Nhô Augusto, que, por isso, pede a Tião que não lhe conte mais coisa alguma e lhe faça a gentileza de fingir para os outros nem o ter visto. É aí que ocorre a menção à égua. $\mathrm{O}$ animal atolado precisaria ser retirado da lama com a ajuda de alguém. E a tarefa, difícil e demorada, é o que permite ao homem desocupar-se mentalmente com o que ouvira de seu visitante, ocupando-se, ao invés disso, com o animal em apuros.

E foi bom passo que nesse dia um homem chamado Romualdo, morador à beira da cava, precisou de ajuda para tirar uma égua do atoleiro, e Nhô Augusto teve trabalho até tarde da noite, com fogueira acesa e tocha na mão. (ROSA, 2001a, p. 384)

No conto, então, a menção à égua não é grande coisa, mas confirma o exercício aconselhado pelo padre da região a Augusto de trabalhar para esquecer a dor, a vergonha, as tentações, podendo ser também um tipo de metáfora da condição mesma de Augusto Matraga, que, com o tempo, depois das sofríveis notícias, mas da bem-sucedida tarefa de desatolar a égua, diz à Mãe Quitéria estar sentindo, finalmente, diminuído o peso sobre suas costas. Isto é, também ele estava conseguindo sair do atoleiro. 
Se no conto de Sagarana a passagem não ocupa mais do que uma linha, no Grande Sertão: Veredas as menções aos cavalos são muitas. Riobaldo fala do bafejo deles, do som dos cavalos que se aproximam, de seu rinchar e de seu relinchar, e até, num neologismo, de seu "resfol" (algo que nomearia a respiração ofegante). Quando mencionados, em geral, tais animais ocupam as cenas de andança e de guerra pelo sertão, participando, com efeito, do código estabelecido naquela região. Neles, não se atirava, fossem cavalos de tenentes, fossem cavalos de bandos rivais, como os de Zé Bebelo ou mesmo os de Hermógenes, o desleal. Na Fazenda Sempre-Verde, aliás, Sô Candelário, ao proferir sua acusação a Zé Bebelo, lista alguns crimes. São eles, na lei sertaneja, a traição, o descumprimento de palavra e, enfim, o roubo de cavalos. Necessários ao combate, às longas viagens, os animais são cuidados e recebem afeto de alguns. Fafafá, dentre os jagunços, destaca-se no amor que sente pelos cavalos. Quando de sua matança, na Fazenda dos Tucanos, é dele o maior desespero, embora Riobaldo testemunhe a tristeza de todos.

Cerca de noventa vezes, o narrador menciona os cavalos. Eles ocupam, porém, um papel acessório na estória, com exceção do evento que acabo de mencionar, em que os "hermógenes", "os mais malditos", seguindo ordens de seu líder, ferem os animais para prejudicar seus rivais: "não se podia ter mão naquela malvadez" (ROSA, 2001, p. 356). O massacre é narrado minuciosamente, conforme as formas que os animais adquirem como reativos à dor e especialmente quanto aos sons que eles expelem. Riobaldo emprega palavras que remetem à força desses sons, fazendo-os variados, para torná-los capazes de descrever as diferenças entre eles.

- "A que estão matando os cavalos!..."

Arre e era. Aí lá cheio o curralão, com a boa animalada nossa, os pobres dos cavalos ali presos, tão sadios todos, que não tinham culpa de nada; e eles, cães aqueles, sem temor de Deus nem justiça de coração, se viravam para judiar e estragar, o rasgável da alma da gente - no vivo dos cavalos, a torto e direito, fazendo fogo! Ânsias, ver aquilo. Alt'-e-baixos entendendo, sem saber, que era o destapar do demônio - os cavalos desesperaram em roda, sacolejados esgalopeando, uns saltavam erguidos em chaça, as mãos cascantes, se 
deitando uns nos outros, retombados no enrolar dum rolo, que reboldeou, batendo com uma porção de cabeças no ar, os pescoços, e as crinas sacudidas esticadas, espinhosas: eles eram só umas curvas retorcidas! Consoante o agarre do rincho fino e curtinho, de raiva - rinchado; e o relincho de medo curto também, o grave e rouco, como urro de onça, soprado das ventas todas abertas. Curro que giraram, trompando nas cercas, escouceantes, no esparrame, no desembêsto - naquilo tudo a gente viu um não haver de dôidas asas. Tiravam poeira de qualquer pedra! Iam caindo, achatavam no chão, abrindo as mãos, só os queixos ou os topetes para cima, numa tremura. Iam caindo, quase todos, e todos; agora, os de tardar no morrer, rinchavam de dôr - o que era um gemido alto, roncado, de uns como se estivessem quase falando, de outros zunido estrito nos dentes, ou saído com custo, aquele rincho não respirava, o bicho largando as forças, vinha de apertos, de sufocados. (ROSA, 2001, p. 355-356)

Para explorar os ruídos dos animais, observamos o narrador elaborar três mecanismos de caracterização. Ele recorre à adjetivação do rincho dos cavalos: por exemplo, "fino e curtinho", "grave e rouco", "saído com custo"; recorre à comparação, "como se estivessem quase falando", "como urro de onça"; e recorre à variação do nome correspondente à vocalização equina: "rincho", "relincho", "urro", "fala", "zunido". Ao diferenciá-los, ele faz com que nós próprios busquemos variar tais sons em nossa imaginação, e a quantidade da dor sentida pelos animais funciona como uma espécie de motivação para essa variação. Os cavalos sofrem com urgência, diz o narrador, suando de dor, espelindo sons distintos e, assim, através da descrição dos urros dos cavalos, somos enredados por seu sofrimento, por conta, devo insistir, não só da matança e nem tanto da matança, mas sobretudo por conta dos sons múltiplos que a matança gera.

\section{Os cavalos iliádicos nas anotações de João Guimarães Rosa e algumas cenas da Ilíada}

Se o pranto dos cavalos nos fisga a atenção, tamanha a criatividade do relato de Riobaldo, poderíamos nos arriscar a dizer que nosso autor, 
também ele, teria sido fisgado pelo terror dos rinchos dos equinos que uma guerra pode provocar. Em meio a seus registros de leitura realizados provavelmente durante sua estada em Paris em 1950, temos em seu caderno de anotações de leitura, em posse do IEB na USP, na seção concernente à Ilíada, a seguinte anotação: "O pranto dos cavalos".

Nessas anotações sobre a Ilíada, Rosa subscreve ideias, personagens e entrechos, por vezes fazendo citações, por vezes, apenas menções indiretas e, em geral, apontando as páginas, embora nem os versos nem os cantos, da origem do registro. Na folha em que encontramos a referência ao pranto dos animais, lemos:

m\% - Homero "mata" Pátrocles a prestações

"ungí-lo com ambrosia" (pg. 310)

(A sacra luta pelos cadáveres. O horror à profanação dos mortos - p. 320)

"the bright-eyed Achaens" (pg. 320)

(A pororoca - pg. 323)

O giganteso Ájax

(O pranto dos cavalos - pg. 327)

(A mísera condição humana, neste mundo = pg. 328)

"the stalwart Menelaus"

$[\ldots]$

(CITAÇÃO IMPORTANTE!)

"But for the moment glory is my aim" (pg. 340)

(ROSA, Documento E 17, p. 21, conforme a grafia original)

Pelo conjunto, a anotação sobre "o pranto dos cavalos" parece se referir a duas passagens ou a uma das duas passagens que serão analisadas a seguir.

É no canto XVI, que o poeta “"mata' Pátrocles a prestações”. Aí também o grande amigo de Aquiles perfura o ventre do escudeiro de Sarpédon. Este, em resposta, mira Pátroclo com sua lança, mas não o acerta. Perfura, em seu lugar, o flanco direito de Pédaso, o único mortal dentre os cavalos de Aquiles (curiosamente, um terceiro cavalo, fugindo à regra homérica de uma parelha), que, depois de berrar, bale ao ser atingido. Ou como, na tradução de Frederico Lourenço (2013), solta um mugido. 
Quando já estavam perto, avançando um contra o outro, foi então que Pátroclo matou o glorioso Trasimelo, que era o valoroso escudeiro do soberano Sarpédon: atingiu-o no baixo-ventre e deslassou-lhe os membros. Todavia Sarpédon, não lhe acertou com a lança luzente, arremetendo em seguida; mas atingiu o cavalo, Pédaso, com a lança no ombro direito. O cavalo relinchou [๕̌ $\beta \rho \alpha \chi \varepsilon]$ ao expirar

o sopro vital e caiu com um mugido [ $\mu \alpha \kappa \omega ́ v]$ no pó. (Ilíada, XVI, v. 462-469).

Nesse trecho do canto XVI da Ilíada, o poeta adota dois verbos diferentes [๕̌ $\beta \rho \alpha \chi \varepsilon$, aoristo do $\beta \rho \alpha \chi \varepsilon \tilde{i} v$; e $\mu \eta \kappa \alpha ́ o \mu \alpha 1$, na forma do particípio $\mu \alpha \kappa \omega ́ v]$ daquele que seria o verbo corrente para descrever a

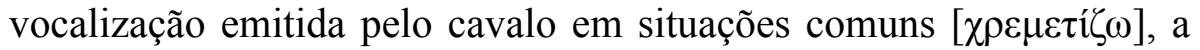
qual nomearíamos "relinchar" em língua portuguesa. Há a escolha dupla, portanto, de designar diferentemente o relinchar do cavalo e os barulhos que esse mesmo animal teria produzido ao ser acertado fatalmente, por meio da escolha de verbos que não são direta ou denotativamente próprios a seus sons. ${ }^{3}$

No primeiro caso, o uso do ع̌ $\beta \rho \alpha \chi \varepsilon$ que viria do incerto $\beta \rho \alpha \chi \varepsilon \tilde{\mathrm{i} v}$, remete ao ruído que fazem as armaduras ou as armas pelo choque ou pelo barulho que o combate causa, como no Canto IV (v. 420): "terrivelmente ressoou [` $\beta \rho \alpha \chi \varepsilon]$ o bronze sobre o peito do soberano"; ou como no Canto XIV, (vs. 419-420), em referência a Heitor: "A lança caiu-lhe da mão, mas o escudo foi atirado por cima,/ assim como o elmo; e à volta dele ressoaram [ $\beta \rho \alpha ́ \chi \varepsilon]$ as armas de bronze". Se bem que esse verbo pode também expressar um grito, como acontece em outra passagem da Ilíada, no canto V (vs. 859-861), e se trata do grito possante de um

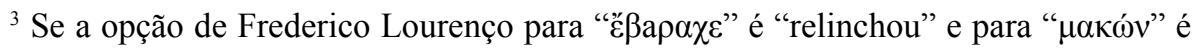
"com um mugido", Carlos Alberto Nunes opta por "relinchando" e "a estrebuchar" respectivamente, enquanto Haroldo de Campos prefere "arqueja" para "ع $\beta \rho \alpha \chi \varepsilon$ " e

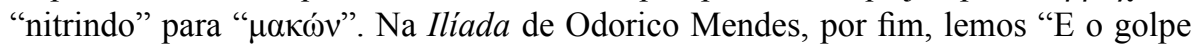

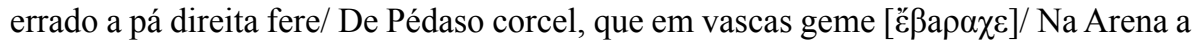
espernear [ $\mu \alpha \kappa \omega ́ v]$ e arcando expira" (aqui, equivalendo aos versos 393 a 395).
} 
deus, equivalente ao de muitos homens: "Urrou [ع̌ $\beta \rho \chi \chi \varepsilon]$ então o brônzeo Ares,/ como urram nove mil ou dez mil homens na guerra, que se juntam no conflito de Ares."

Com o uso do $\mu \eta \kappa \alpha ́ o \mu \alpha 1$, por outro lado, somos informados de que a reação sonora do cavalo se assemelharia ao balir de um carneiro ou de uma ovelha, de um bode ou de uma cabra, e no limite, a um berro ou a um grito, sendo, de fato, o som de um grito, o que o carneiro ou a ovelha ou a cabra ou o bode usualmente fazem. $O$ som, enfim, que esses animais emitem é mesmo bem mais estridente do que o som que o cavalo faz, sendo ainda interessante, nesse sentido, mencionar o aspecto onomatopeico do verbo, que busca reproduzir o som que fazem tais animais (ovelha, carneiro, bode e cabra), distinto sonoramente daquele que o cavalo faz.

$\mathrm{Na}$ Odisseia, observamos alguns usos que o poeta faz do $\mu \eta \kappa \alpha ́ o \mu \alpha \alpha$. Alguns deles são livres, como no caso que mais nos interessa da Ilíada. Primeiramente, contudo, vale destacar o uso convencional, em que o verbo denota de fato o som que emitem as ovelhas. Isso se dá no canto IX, quando Odisseu e seus companheiros, hóspedes de Polifemo, sentem-se ameaçados. Amanhecido o dia, os machos dos rebanhos do ciclope saem

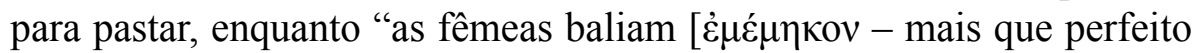

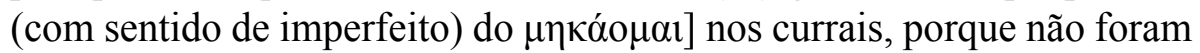
ordenhadas" (Odisseia, IX, 438-439, tradução de Frederico Lourenço). ${ }^{4}$

No canto X, como o poeta da Odisseia emprega o verbo em outras situações, é um veado, portanto nem carneiro nem ovelha nem cabra nem bode, o animal que, sendo atingido pela lança de Odisseu, berra ou bale ou geme.
Mas enquanto caminhava, e estando já perto da nau recurva, um deus se apiedou da minha solidão e mandou ao meu encontro um enorme veado de altos chifres, que vinha da sua pastagem no bosque em direção ao rio para beber; oprimia-o a força do sol.
Acercando-me dele, acertei-lhe no meio do dorso:

\footnotetext{
${ }^{4}$ Os trechos citados em português tanto da Odisseia quanto da Ilíada serão sempre conforme a tradução de Frederico Lourenço $(2013 ; 2011)$.
} 
a lança de bronze trespassou-lhe o corpo

e caiu no chão com um mugido [ $\mu \alpha \kappa \omega ́ v]$; dele se evolou a vida.

(Odisseia, X, 156-163)

No canto XVIII, temos a única ocorrência desse verbo em Homero para um homem. Trata-se do verdadeiro mendigo de Ítaca que, ameaçado pelo novo (Odisseu disfarçado) desafia-o para o confronto. Então, na disputa, Iro, ao ter alguns ossos quebrados, bale, berra ou geme de dor.

Ao levantarem as mãos, Iro bateu-lhe no ombro direito, mas Ulisses atingiu-o no pescoço, debaixo da orelha, e estilhaçou-lhe os ossos: da boca de Iro correu logo o rubro sangue. Caiu no chão com um mugido [ $\mu \alpha \kappa o ́ v]$ e rangeu os dentes, esperneando com os pés contra a terra. (...)

(Odisseia, XVIII, 98)

Nessas duas últimas passagens, do canto X e do canto XVIII,

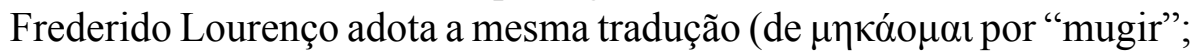
ou mais precisamente, de $\mu \alpha \kappa \omega ́ v$ por "com um mugido") da primeira passagem a que aludimos, a do som que o cavalo de Aquiles emite ao ser atingido: "O cavalo relinchou [๕ß $\beta \rho \alpha \chi \varepsilon]$ ao expirar o sopro vital/ e caiu com um mugido [ $\mu \alpha \kappa \omega ́ v]$ no pó” (Ilíada, XVI, v. 468-469).

Por fim, no canto XIX, ainda da Odisseia, o poeta descreve o grunhido emitido pelo javali culpado da cicatriz na perna de Odisseu antes de ser morto pelo Laertíade, utilizando novamente $\mu \eta \kappa \alpha ́ o \mu \alpha$ : "Mas Ulisses atingiu-o, acertando-lhe na espádua direita:/ a ponta da lança brilhante trespassou-o completamente/ e caiu no chão com um grunhido [ $\mu \alpha \kappa \omega ́ v]$; dele se evolou a vida" (Odisseia, XIX, 452-454). Agora, a opção de Frederico Lourenço para o particípio aoristo $\mu \alpha \kappa \omega ́ v$ não será mais "com um mugido", mas "com um grunhido".

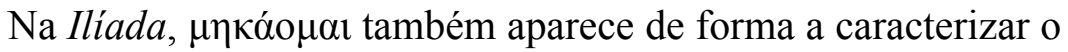
balir da ovelha no canto IV, verso 435, mas curiosamente a intenção é a de caracterizar as falas dos variados grupos que compunham a aliança troiana, uma vez que se trata de um símile. Nesse caso, vemos o particípio perfeito $\mu \varepsilon \mu \alpha \kappa v \tilde{\imath} \alpha$ : 
Quanto aos Troianos, tal como as ovelhas de um homem rico esperam em número incontornável pela ordenha do alvo leite, balindo $[\mu \varepsilon \mu \alpha \kappa v i ̃ \alpha 1]$ sem cessar porque ouvem as vozes dos cordeiros -

assim se elevou o clamor dos Troianos pelo vasto exército. É que não tinham todos a mesma fala, nem a mesma língua, mas as línguas estavam misturadas, pois eram povos de muitas terras.

(Ilíada, IV, 433-438)

Noutra passagem da Ilíada, o mesmo verbo, apesar de estar na forma participial, nesse caso um particípio perfeito $(\mu \varepsilon \mu \eta \kappa \omega \varsigma)$, nomeia

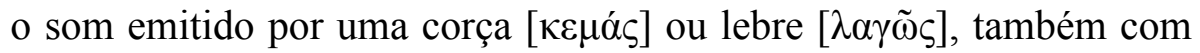
vistas a um paralelo:

Tal como quando dois galgos de afiados dentes, peritos na caça perseguem uma corça ou lebre com persistência e sem tréguas em terreno arborizado e o animal, aos guinchos [ $\mu \varepsilon \mu \eta \kappa \omega ́ \varsigma]$, corre em frente -

assim o Titida e Ulisses, saqueador de cidades, impediram

a Dólon o acesso ao exército e sem tréguas corriam atrás dele. (Ilíada, X, 360-364)

Segundo Edouard Délébecque, em Le Cheval dans l'Iliade (1951, p. 51), o poeta, que teria "une oreille attentive" ("um ouvido atento"), conheceria (e faria uso de) um vocabulário rico e nuançado capaz de diferenciar o som habitual dos cavalos, seu relinchar $(\chi \rho \varepsilon \mu \varepsilon \tau i \zeta \zeta \omega$, verbo que aparece na Ilíada, no canto XII, v. 51, em que os corceis troianos não ousam atravessar a vala e, por isso, relincham), do som como aquele que o cavalo Pédaso de Aquiles emite nos momentos da dor limítrofe à sua morte [ $\mu \eta \kappa \alpha ́ o \mu \alpha 1-I l i ́ a d a, X V I, 469]$. O poeta, portanto, insisto, teria o cuidado de designar diversamente o relinchar do cavalo ["le hennissement du cheval"] do gemido que esse mesmo animal, ou outros, como o javali, a corça, a lebre, o veado e até mesmo o mendigo da Odisseia, teriam dado ao serem feridos. Por isso, Richard Janko diz em seu comentário ao canto XVI da Ilíada: “(...) $\mu \alpha \kappa \omega ́ v$ suits only animals and the comical 


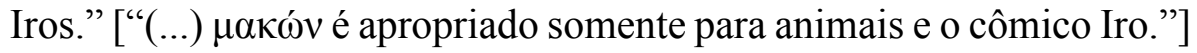
(JANKO, 1994, p. 378).

João Guimarães Rosa parece ter percebido isso em sua leitura e eu arriscaria a dizer que ele pode ter consultado o texto grego, uma vez que dispunha de mais de uma tradução da Ilíada e de algum conhecimento sobre a língua de Homero. De Homero, na verdade, encontramos cinco exemplares na biblioteca pessoal do autor: três traduções da Odisseia (para o francês, para o alemão e para o inglês) e, o que mais nos interessa, duas traduções da Ilíada, uma para o alemão e finalmente uma para o inglês, realizada por Emile Victor Rieu, preparada para a Penguin, sendo esta a que parece estar na base de suas anotações. ${ }^{5}$

Nela, o ruído que o cavalo Pédaso faz ao ser ferido de morte é próximo a um choro, e é, porque não o habitual, um ruído que chama mais atenção do que chamaria caso o tradutor optasse por nomeá-lo com aquele que o cavalo normalmente faz. E. V. Rieu escolhe o verbo "to whinny" (e não "to neigh", o mais comum) para descrever o som exalado pelo animal, que "tombou rinchando" ("fell whinnying"). Contudo, se Rieu faz seu leitor reparar no som do cavalo, diferente do relinchar, ainda assim ele se utiliza de um som que é próprio ao cavalo, o que não é o procedimento homérico nem será o rosiano. "The horse keeled over, gasping for breath, fell whinnying in the dust, and its life departed" (RIEU, 1950, p. 286), é o que lemos na tradução da Ilíada de onde o autor pode ter retirado as citações ou referências que faz em seu caderno de leitura, uma vez que quando as citações ou referências não estão em português ("O pranto dos cavalos" - p. 328), elas estão em inglês ("the horse-taming Trojans" - p. 57), ou mesmo misturam inglês e português (como nessa divertida

\footnotetext{
${ }^{5}$ De acordo com Suzi Sperber (1976), conhecemos uma lista dos livros da biblioteca pessoal do autor. Há cinco volumes de Homero: duas traduções da Ilíada, uma em inglês (Homer, The Iliad, Harmondsworth, Middlesex, Penguin Books, 1950. Translated by Emile Victor Rieu) e outra em alemão (Homer, Ilias, Leipzig, Dieterich'sche Verlagsbuchhandlung, 1938. Übersetzt von Thassilo von Scheffer); três traduções da Odisseia, uma em francês (Homère, Odyssée, Paris, Garnier, 1941. Traduite par Médéric Dufour et Jeanne Raison), outra em alemão (Homer, Odyssee, Berlin, Leipzig, TempelVerlag, 2 vol. [n.d.]. Übersetzt von Johann Heinrich Voss), e uma terceira em inglês (Homer, The Odyssey, Harmondsw, Penguin, 1948. Translated by Emile Victor Rieu).
} 
passagem em que relaciona Tersistes e Goebbels: "He had a game foot and was bandy-legged. $\mathrm{m} \%=$ comparar com Goebbels" - p. 27).

Porém, como Rosa anota "o pranto dos cavalos" (não "do cavalo", no singular), a menção pode nos levar ainda ao canto seguinte, o XVII. A cena agora é aquela em que os outros dois cavalos de Aquiles, desta vez os imortais, imóveis no campo de batalha, choram a morte de Pátroclo. Na tradução de E. V. Rieu, temos:

Far from the conflict, the horses of Achilles had been

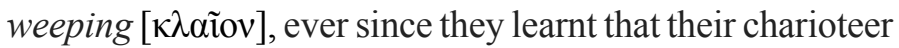
had been brought down in the dust by man-slaying Hector. Automedon, Diores' strong son, did all he could with them: he tried lashing them with his whistling whip; he tried coaxing them; he tried threats. But the pair refused either to go back to the ships and the broad Hellespont, or into battle with the Greeks. Firm as a gravestone planted on the barrow of a dead man or woman, they stood motionless in front of their beautiful chariot, their heads bowed to the earth. Hot

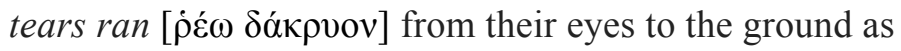

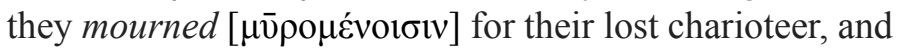
their luxuriant manes, falling to the ground from the collar on both sides of the yoke, were soiled in the dust.

(Iliad, XVII, vs. 432-440. Translated by Emile Victor Rieu)

O verbo no texto grego é $\kappa \lambda \alpha i ́ \omega$, chorar, lamentar. E depois vem seu sinônimo, $\mu$ v́ $\omega$. A tradução de Frederico Lourenço para o trecho é:

Ora, os cavalos de Aquiles, afastados do combate, estavam chorando [ $\kappa \lambda \alpha$ oiov $]$ desde o momento em que primeiro ouviram que seu cocheiro tombara na poeira, chacinado por Heitor. $[\ldots]$

Tal como fica imóvel uma coluna sobre um túmulo de um homem morto ou de uma mulher assim imóveis permaneciam com o carro lindíssimo, vergando as cabeças até ao chão. Das suas pálpebras

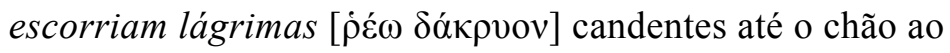

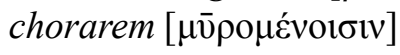


com saudades do seu cocheiro. Sujavam-se suas crinas fartas, que caíam debaixo da coleira de ambos os lados do jugo.

(Ilíada, XVII, 426-428; 434-440)

Confirma-se, então, o procedimento adotado pelo poeta na passagem anterior: associar aos cavalos um verbo que não é usualmente associado ao mundo deste animal e, neste caso, nem mesmo associado ao mundo animal. Escutamos, aí, o pranto dos cavalos, ou enxergamos cavalos que choram. Tanto $\kappa \lambda \alpha i ́ \omega$ (na passagem, temos o particípio presente $\kappa \lambda \alpha$ ĩov) é um verbo associado aos homens, quanto $\mu$ $\rho \omega$

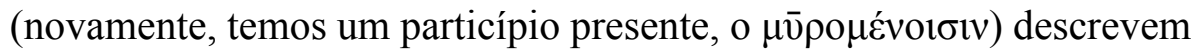
a condição, essencialmente humana ou divina, de derramar lágrimas. No segundo caso ainda, o aspecto humanizado da ação é realçado pelo complemento que aparece no dativo: os cavalos choravam "de saudade" [ $\pi$ ó $\omega$ ] de seu cocheiro. ${ }^{6}$ Assim, tanto Zeus derrama lágrimas (Il. XVII, 441; XIX, 340), quanto a sombra de Pátroclo no Hades (XXIII, 106) se lamenta, e também os mortais pranteiam (para citar apenas uma passagem: $I l$. VI, vs. 371-373). É certo que o $\mu$ v́ $\rho \omega$ pode descrever um fluxo de lágrimas não humano, tal qual o fluxo das águas de um rio, como o Escamandro, que diz, em primeira pessoa (revelando seu aspecto humanizado então também por sua capacidade mesma de narrar):

(...) Pois afirmo que a sua força e a sua beleza de nada lhe servirão,

nem as belas armas, que talvez venham a jazer no fundo da lagoa, cobertas de lama; e ao próprio Aquiles

eu cobrirei com areia e verterei [ $\mu v \rho$ óov] por cima dele quantidades

incontáveis de seixos e nem os Aqueus saberão onde recolher seus ossos, com tal fundura de lama o cobrirei.

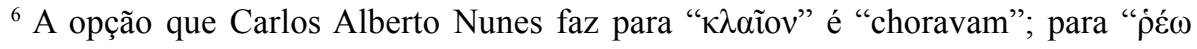

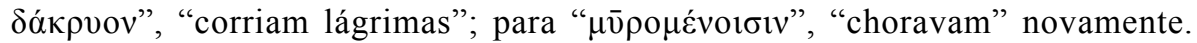

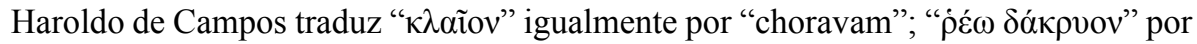

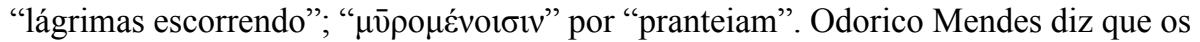

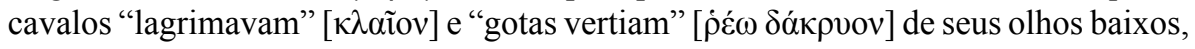

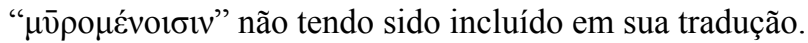


Pois aqui mesmo será a sua sepultura e não precisará de um túmulo elevado, quando os Aqueus the fizerem o funeral. (Ilíada, XXI, 316-323)

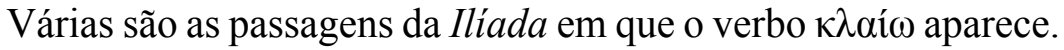
No canto XVIII, Tétis pergunta a Aquiles (v. 73): "Por que choras, meu

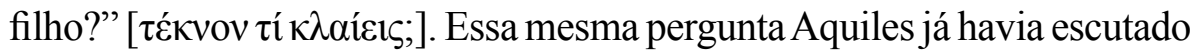
da mãe no canto I (v. 462), depois de se dirigir a ela em prece, em busca de consolo. No canto II (v. 263), será a vez de Tersites (o mesmo que Rosa compara com o ministro de propaganda da Alemanha nazista de Hitler), escutando de Odisseu a ameça de ser mandado embora da assembleia "a chorar" [ $\kappa \lambda \alpha i ́ o v \tau \alpha]$. No canto III, chora Helena (v. 176). No canto VII (v. 427), choram os troianos, mas Príamo impede suas lamentações. No canto XIX, chora Briseida a morte de Pátroclo (v. 286). No XXII (v. 87), choram Heitor e sua mãe temendo que ele tenha o mesmo destino que Pátroclo. E todos sabemos que ele terá. Por isso, vão ainda chorar muitos. Chora Príamo, num choro que nos leva junto, atravessando a muralha para buscar o corpo de seu filho (Il. XXII, v. 427); chora novamente Hécuba (Il. XXII, v. 430) e chora Andrômaca em meio às mulheres troianas que, como ela, se emocionam (Il. XXII, 515).

Ora, tantas referências (e, aqui, menciono apenas algumas das muitas na Ilíada) revelam uma característica do verbo $\kappa \lambda \alpha i ́ \omega$ que conta para a análise que proponho: inimigos, amigos, de classes ou de gêneros distintos, quem chora são personagens humanos ou humanizados (pois também os deuses e as sombras do Hades derramam lágrimas). Tal aspecto, poderíamos dizer, também se faz ver no uso do verbo $\mu$ uma vez que o caso comum de exceção, usá-lo para descrever o fluxo das águas fluviais, confirma a identidade humanizada do rio, que fala.

Nesta passagem do canto XVII, que pode ter sido a que levou Rosa a escrever em seu caderno de anotações "o pranto dos cavalos" (e pela análise conduzida até aqui, ela seria a mais correta, pois só aí os cavalos de fato "choram"), verificamos, portanto, a capacidade de se emocionar desses animais. Por outro lado, se no canto XVI o terceiro corcel de Aquiles não verte lágrimas, ele, ainda assim, realiza uma ação que não é própria à sua natureza, posto que "bale" ou, como quer a 
tradução de Lourenço, "solta um mugido". O que se tem com isso, na soma dessas duas passagens, é, portanto, a revelação de um procedimento homérico que toma emprestado, quando a ação pede, um vocabulário que não lhe cabe propriamente, mas que, sendo empregado, amplia seus efeitos - seja tornando o cavalo mais humano, ao fazê-lo chorar, ${ }^{7}$ seja tornando-o menos humanizado, ao fazê-lo balir.

\section{Cavalos que choram em outros registros: considerações finais}

Num outro registro, Rosa dispensa atenção à matança de animais em nova situação de guerra (e, aqui, há uma desconfiança de que o autor tenha sido enredado não somente pela imaginação do som que, distinto do habitual, os animais emitem ao serem feridos, como pode ter ocorrido durante sua leitura da Ilíada, mas pela provável audição desse som). Vice-cônsul em Hamburgo, de 1938 a 1942, o escritor anota num outro caderninho, uma espécie de diário de guerra, percepções diversas do que vê e vivencia na Alemanha, de toques de recolhimento a placas que demarcavam no espaço público os lugares interditados aos judeus, de roteiros de passeios a notícias, assim como descrições dos barulhos e efeitos das bombas. $\mathrm{Na}$ quarta página desse diário, escreve:

\footnotetext{
${ }^{7}$ Como me lembrou Teodoro Rennó Assunção, a quem sou muita grata pela interlocução por ocasião do V Seminário do NEAM (Letras-UFMG), essa caracterização humanizada dos cavalos de Aquiles será reforçada no canto XIX, na cena em que o cavalo imortal Xanto responde a Aquiles, depois de ser dotado de fala pela deusa Hera, negando que ele e o outro cavalo imortal tivessem tido qualquer responsabilidade na morte de Pátroclo. Tal caracterização será reforçada também no canto XXIII, quando Antíloco, filho de Nestor, dirige quatorze versos (vs. 403-416) aos cavalos que conduz na corrida, pressionando-os a ganhá-la e orientando-os a como ultrapassar o carro de Menelau. Os cavalos demonstram ser capazes de entender o recado, pois, como resposta, atemorizados pela ameaça, apressam o passo. No mesmo canto, Menelau também repreende verbalmente seus cavalos, os quais reagem a partir de sua fala (Il. XXIII, 441-447). Há, portanto, nessas duas cenas, a sugestão de uma capacidade de compreensão, por parte dos cavalos, da fala de seus cocheiros.
} 
5.IX - sexta-feira: Fui para Berlim.

6.IX - sabado: reunião consular.

7.IX - Jantei com o Navarro, junto com o Waldemar.

\section{ALARME!}

Estava hospedado no "Eden".

Cheguei no hotel, depois de dado o alarme. Cairam as bombas; terrivel!

"Volltreffer" no hotel.

(Parte do 5o andar foi espatifada. Dachgarten, lavanderia.

Criado do elevador. O capitão e sua valise.)

Continuei na cama. Puz os oculos.

Fragror tremendo. Bombas poderosas.

Fim-de-mundo.

(Bomba no Jardim Zoológico. Camelos mortos. Bichos outros mortos - bombeados ou metralhados. Os inglêses por certo visavam os soldados da Flak, que há no zoo - canhão pesado:)

Não havia água, pela manhã.

(ROSA. Diário de Guerra de João Guimarães Rosa, p. 4, conforme a grafia original)

Sabe-se que o primeiro ataque ao Zoológico de Berlim durante a Segunda Guerra aconteceu precisamente na madrugada de 8 de setembro de 1941, o que casa com a data informada no registro da página destacada do diário de Rosa, concernente à noite do dia 7: "7.IX - Jantei com o Navarro, junto com o Waldemar", sendo razoável sugerir portanto que nosso autor pode mesmo ter ouvido relinchos, berros e balidos, uma vez que o Hotel Éden ("Estava hospedado no 'Eden"”), um dos hoteis mais elegantes da cidade, distava quatrocentos e cinquenta metros do Zoológico da capital. ${ }^{8}$

Para finalizar, quero propor que essas menções de Rosa ao mundo dos animais, dos cavalos, em registros de distintos gêneros do autor, não revelariam uma admiração ou um encantamento pelo mundo dos animais que separaria este último do mundo dos homens. Numa conversa

\footnotetext{
${ }^{8}$ A distância foi calculada pelo google.maps, acessado no dia 22 de outubro de 2018, às 15:22h. In: https://www.google.com/maps/
} 
com seu amigo alemão, precisamente depois de ser perguntado sobre sua participação arriscada na emissão de passaportes para judeus que buscavam fugir da Alemanha, ${ }^{9}$ ele diz:

Tudo isso é verdade, mas não se esqueça de meus cavalos e de minhas vacas. As vacas e os cavalos são seres maravilhosos. Minha casa é um museu de quadros de vacas e cavalos. Quem lida com eles aprende muito para sua vida e a vida dos outros. Isto pode surpreendê-lo, mas sou meio vaqueiro, e como você também é algo parecido com isto, compreenderá certamente o que quero dizer. Quando alguém me narra algum acontecimento trágico, digo-lhe apenas isto: "Se olhares nos olhos de um cavalo, verás muito da tristeza do mundo!" Eu queria que o mundo fosse habitado apenas por vaqueiros. Então tudo andaria melhor. (LORENZ, 1983, p. 323)

As referências aos bichos e a seus rinchos enfim, porque adotam e atualizam o procedimento homérico (que, como já dissemos, toma emprestado, quando a ação pede, um vocabulário que não lhe cabe propriamente, mas que, sendo empregado, amplia seus efeitos - seja tornando o cavalo mais humano, quando ele chora, seja o tornando menos humano, quando ele bale), servem à linguagem que Rosa cria em busca de descrever melhor o sertão das guerras. Não somente em sua literatura, nosso autor escolhe deixar os homens de lado ou retirá-los, mesmo que aparentemente, do papel principal por alguns momentos, para dizer o que são capazes de fazer. Em Homero, vemos (e Rosa provavelmente enxergou isso) escolhas de verbos que não seriam usuais. ${ }^{10}$ Em Rosa, porque ele repete esse procedimento homérico, o que vemos é uma apropriação fazer confluir naquele sertão as guerras diversas, que se

\footnotetext{
${ }^{9}$ Gunter Lorenz diz: "Sabe-se também que como diplomata e exercendo as funções de cônsul geral do Brasil em Hamburgo, você provocou Hitler fora das normas da diplomacia, e salvou a vida de muitos judeus...” (LORENZ, 1983, p. 323).

${ }^{10}$ C. M. Bowra (1952, p. 169) observa a proximidade entre o herói e seu cavalo, bem como a dor do animal quando da morte do guerreiro, como elementos da épica grega, mas não há, com isso, nenhuma proposta de transposição do sofrimento do animal para o homem ou, mais precisamente, de transposição do sofrimento do animal para uma compreensão da guerra.
} 
repetem de Homero a Alemanha ou de Homero ao sertão, dando, uma vez mais, som aos cavalos que choram e balem, como num urro de onça, ou como se estivessem quase falando.

\section{Referências}

\section{Fontes primárias}

ALLEN, Thomas W. (ed.). Homeri Ilias, v. 2-3. Oxford: Oxford University Press, 1931.

CARLOS ALBERTO NUNES. Homero. Ilíada. São Paulo: Hedra, 2011. FREDERICO LOURENÇO. Homero. Ilíada. São Paulo: Penguin Classics; Companhia das Letras, 2013.

FREDERICO LOURENÇO. Homero. Odisseia. São Paulo: Penguin Classics; Companhia das Letras, 2011.

HAROLDO DE CAMPOS. Homero. Ilíada. São Paulo: Arx, 2002. v. II.

ODORICO MENDES. Homero. Ilíada. São Paulo: Ateliê Editorial; Campinas: Editora da Unicamp, 2010.

ROSA, João Guimarães. Diário de Guerra de João Guimarães Rosa. Documento do Acervo de Escritores Mineiros da Universidade Federal de Minas Gerais.

ROSA, João Guimarães. Documento E17 - Caderno de notas de leitura da Ilíada e da Odisséia, das Fábulas de La Fontaine e da Divina Comédia; e uma seção chamada Artes, com descrições de quadros contemplados em museus de Paris. (Série "Estudos para a Obra"). In: Arquivo Guimarães Rosa (AGR), do Instituto de Estudos Brasileiros (IEB/USP).

ROSA, João Guimarães. Grande Sertão: Veredas. 20. ed. Rio de Janeiro: Nova Fronteira, 2001.

ROSA, João Guimarães. Sagarana. Rio de Janeiro: Nova Fronteira, 2001a.

VON DER MÜHLL, Peter (ed.). Homeri Odyssea. Basel: Helbing \& Lichtenhahn, 1962. 


\section{Fontes secundárias}

ASSUNÇÃO, Teodoro Rennó. Nota crítica à "bela morte" vernantiana. Classica, São Paulo, v. VII/ VIII, p. 53-62, 1994-1995.

BOWRA, Maurice. Heroic Poetry. London: Macmillan, 1952.

DE LARA, Cecília. Grande Sertão: Veredas: Processos de criação. Scripta, Belo Horizonte, v. 2, n. 3, p. 41-49, 2 sem. 1998.

DELEBECQUE, Edouard. Le Cheval dans l'Iliade, suivi d'un lexique du cheval chez Homère et d'un essai sur le cheval pré-homérique. Paris: Librairie C. Klincksieck, 1951.

DETIENNE, Marcel. Les maîtres de vérité dans la Grèce archaïque. Paris: Librairie Générale Française, 2006. [1 ${ }^{\text {ère }}$ édition: François Maspero, 1967].

GINZBURG, Jaime. Notas sobre o "Diário de Guerra” de João Guimarães Rosa. Aletria, Belo Horizonte, v. 20, n. 2, p. 95-110, 2010.

GRAZIOSI. Inspiração divina e técnica narrativa na Ilíada. Classica, Belo Horizonte, v. 29, n. 1, p. 171-191, 2016.

JANKO, Richard. The Iliad: A Commentary (General Editor G. S. Kirk). Cambridge: Cambridge University Press, 1994. v. IV: books 13-16.

LOPES DA COSTA, Lorena. Dos ventos: história, crítica literária e linguagem em Grande Sertão: Veredas. Belo Horizonte: Fino Traço, 2013. v. 1

LORENZ, Günter. Diálogo com Guimarães Rosa. In: COUTINHO, E. (ed.). Guimarães Rosa. Rio de Janeiro: Civilização Brasileira, 1983. (Coleção Fortuna Crítica 6, p. 62-97).

MARTINS COSTA, Ana Luiza Borralho. Homero no Grande sertão. Kleos, Rio de Janeiro, v. 5-6, p. 79-124, 2002.

MARTINS COSTA, Ana Luiza Borralho. Rosa, ledor de Homero. Revista USP, São Paulo, v. 36, p. 46-73, dez./fev. 1997-1999.

ROSA, João Guimarães; MEYER-CLASON, Curt. João Guimrães Rosa: Correspondência com seu tradutor alemão. Rio de Janeiro: Nova Fronteira; Belo Horizonte: UFMG, 2003. 
NAGY, Gregory. The Ancient Greek Hero in 24 hours. Cambridge, Mass.; London: Harvard University Press, 2013.

NAGY, Gregory. The Best of the Achaeans: Concepts of the Hero in Archaic Greek Poetry. Revised Edition by Gregory Nagy. Baltimore: The Johns Hopkins University Press, 1980.

OTTE, Georg. O "Diário Alemão" de João Guimarães Rosa. In: DUARTE, Lélia Parreira (Org.). Veredas de Rosa II. Belo Horizonte: Editora PUC Minas, 2003. v. II, p. 285-290.

PARKER, Robert. On Greek Religion. Ithaca; London: Cornell University Press, 2011.

SPERBER, Suzi. Caos e Cosmos. Leituras de GR. São Paulo: Duas Cidades, 1976.

STARLING, Heloisa; IUPERJ. Lembranças do Brasil: teoria política, história e ficção em Grande Sertão: Veredas. Rio de Janeiro: Revan; UCAM/IUPERJ, 1999.

VERNANT, Jean-Pierre. La belle mort et le cadavre outragé. In:

L'individu, la mort, l'amour. Soi-même et l'autre en Grèce Ancienne. Paris: Éditions Gallimard, 1989. p. 41-79.

VERNANT, Jean-Pierre. Le mythe hésiodique des races: essai d'analyse structurale. Revue de l'Histoire des Religions, Paris, tome 157, p. 21-54, 1960.

VERNANT, Jean-Pierre. Le mythe hésiodique des races: sur un essai de mise au point. Revue de Philologie, Paris, v. 40, p. 247-76, 1966.

WERNER, Christian. O mundo dos heróis na poesia hexamétrica grega arcaica. Romanitas - Revista de Estudos Grecolatinos, n. 2, p. 20-41, 2013.

Recebido em: 6 de novembro de 2019.

Aprovado em: 5 de dezembro de 2019. 